\title{
Could cyanobacteria have made the salinity transition during the late Archean?
}

Herrmann, A. and Gehringer, M. M.*

*Department of Plant Ecology and Systematics, Faculty of Biology, Technical

University of Kaiserslautern, 67663 Kaiserslautern, Germany.

Email: mmgehringer@yahoo.com \& $\underline{\text { mgehring@rhrk.uni-kl.de }}$

\section{Abstract}

Modern molecular evolutionary studies suggest the freshwater origin of cyanobacteria during the late Archean, about $2.7 \mathrm{Ga}$ ago, with an even earlier evolution of oxidative photosynthesis. The large amount of oxygen required to oxygenate the Earth's atmosphere during the Great Oxygenation Event (GOE) 2.4 $\mathrm{Ga}$ is thought to have been produced by large cyanobacterial blooms in the open ocean. This then poses the question as to whether ancient lineages of cyanobacteria would have survived the salinity transition. This study investigates the effect of increasing salinity on the photosynthetic efficiency of two modern day descendants of ancient cyanobacteria, Chroococidiopsis thermalis PCC7203 and the root species, Gloeobacter violaceus PCC7421. Organisms were cultured in fresh, brackish or sea water analogous media under a present atmospheric level (PAL) atmosphere or an atmosphere with reduced $\mathrm{O}_{2}$ and elevated $\mathrm{CO}_{2}\left(\mathrm{rO}_{2} \mathrm{eCO}_{2}\right)$. The net photosynthesis (NP) rates were determined in liquid cultures, while the $\mathrm{O}_{2}$ and redox profiles were determined in pseudomats. While C. thermalis PCC7203 was able to grow under increasing salinities under both atmospheres tested, G. violaceus PCC7421 could not make the salinity change to sea water. NP rates were reduced for $C$. thermalis under increasing salinities, as were the levels of dissolved $\mathrm{O}_{2}$ in the media. A gene screen indicated that $C$. thermalis genome carries genes for both sucrose and trehalose synthesis, whereas G. violaceus has only the later genetic component, suggesting a mechanism for their differing salt tolerances. This study supports the hypothesis of Cyanobacterial evolution in freshwater environments and their transition into increasingly salty environments during the late Archaean, prior to the GOE.

Keywords: Archaean, Cyanobacteria, salinity transition, net photosynthesis, pigments, Chroococidiopsis thermalis, Gloeobacter violaceus. 


\section{Introduction}

The early origin of life is often assumed to have evolved in the deep oceans as this is where the first geochemical records and fossils were identified. Modern evolutionary and geochemical studies, however, indicate that widespread shallow water marine (Heubeck et al., 2016, Homann et al., 2016) and non-marine life was well established in the late Archean (Stueken et al., 2015, Djokic et al., 2017). Furthermore, strong sedimentary evidence exists for terrestrial land biota (Lenton \& Daines, 2017). While the first mats were presumably powered by anoxic phototrophs, oxidative phototrophs would have exhibited higher primary productivity and therefor capable of leaving the clear traces we observe in the geological records today. Cyanobacteria are the pioneer species of modern day biological soil crusts (Büdel et al., 2014) and have demonstrated their diverse adaptability to inhabit environments from hot springs to dry Antarctic mats. The earliest biological mats, whether in fresh or marine shallow water environments, or subaerial, would have been dependent on the primary productivity of early cyanobacteria to provide both biological accessible $\mathrm{C}$ and $\mathrm{N}$.

Recent studies based on the analysis of sequenced cyanobacterial genomes places the origin of cyanobacteria at $\sim 2.7 \mathrm{Ga}$ in a freshwater environment (SánchezBaracaldo et al., 2014, Sanchez-Baracaldo et al., 2017). These studies identified modern day descendents of cyanobacteria that are the most closely related to the cyanobacteria proposed to have lived during the Archean. At the root of the tree is Gloeobacter violaceus PCC7421 and Gloeobacter kilauensis, both unicellular freshwater species. G. kilauensis is a very slow growing organism and unsuited to largescale laboratory investigations (Saw et al., 2013). These strains are of particular interest as they do not contain thylakoids and therefor carry the photosynthetic apparatus on the cell membrane. As the result of this presumed ancient structure, $G$. violaceus keeps tight control of its light harvesting pigments, producing low levels of chlorophyll $a$ and phycobilliproteins (Guglielmi et al., 1981). Chroococcidiopsis thermalis PCC7203, while not located in the cyanobacterial basal clade, is still an anciently derived cyanobacterial species often proposed as an example of the earliest cyanobacteria (Fewer et al., 2002) as they are cryptoendolithic (Budel et al., 2004) and able to withstand desiccation and raised salinities (Bahl et al., 2011, Cumbers \& Rothschild, 2014). It has high UV tolerance, is able to withstand harsh 
desiccation conditions by virtue of its production of a thick exopolymeric substance (EPS) and thick cell walls. Based on these studies, C. thermalis PCC7203 has been proposed as an early Earth terrestrial coloniser and also used as a space coloniser (Billi et al., 2011, Cockell et al., 2011).

It is against this background that we undertook a study to assess the nett photosynthesis activities of modern day descendants of ancient Cyanobacteria, Chroococidiopsis thermalis PCC7203 and Gloeobacter violaceus PCC7421, to grow under increasing salinities under a modern day atmosphere or an atmosphere representative of the Archean.

\section{Materials and Methods}

\section{Cultures}

Cultures of Gloeobacter violaceus PCC7421 and Chroococcidiopsis thermalis PCC 7203 were purchased from the Pasteur Culture Collection and maintained in BG11 (PCC) media on a day night cycle of 16:8 hrs in a Percival culture chamber (E-22L). Daylight illumination was supplemented with red light and far red light LED banks at 20 and $60 \mu$ mols photons $\mathrm{m}^{-2} \mathrm{~s}^{-1}$ respectively.

\section{Growth curves.}

C. thermalis PCC7203 and G. violaceus PCC7421 were used in growth curve experiments to compare the effects of increased salinities and altered atmospheres on their growth. Early stationary phase cultures were used to inoculate media (BG11, BG11:ASNIII \& ASNIII as per PCC) at an $\mathrm{OD}_{600}$ of 0.1 and pipetted in $200 \mu \mathrm{l}$ volumes into 5 wells of a 96 well tissue culture plate and incubated at $20 \mu \mathrm{mol}$ photons $\mathrm{m}^{2} \mathrm{~s}^{-1}$ for G. violaceus and $60 \mu \mathrm{mol}$ photons $\mathrm{m}^{2} \mathrm{~s}^{-1}$ for $C$. thermalis. A duplicate plate was incubated in an airtight culture chamber that was gassed daily with $\mathrm{rO}_{2} \mathrm{eCO}_{2}$ gas at 600 and 1000 ppm respectively. Cultures were briefly ( 10 min.) exposed to PAL conditions every second day when their optical density at $650 \mathrm{~nm}\left(\mathrm{OD}_{650}\right)$ was measured in a microtiter plate reader (Multiscan FC, ThermoFisher Scientific, USA) after $30 \mathrm{~s}$ of shaking.

\section{Nett photosynthesis experiment.}


Cultures were grown at $24{ }^{\circ} \mathrm{C}$ at $65 \%$ humidity in ventilated $\mathrm{T}_{75}$ suspension culture flasks (Sarsted, Germany). Large scale cultures ( $\left.T_{175}\right)$, in early stationary phase, were split into 2 sets of triplicates, drained of medium and resuspended in media representing one of the following conditions: fresh (BG11), brackish (BG11:ASNIII, $1: 1$ ) and salty (ASNIII) culture conditions, with salinities of 1, 16 and 29,5 psu (pratical salinity units) respectively ( conductivity measurements; inoLab Cond720, WTW, Germany). The $50 \mathrm{ml}$ cultures in $\mathrm{T}_{75}$ ventilated flasks were placed in airtight culture containers with holes $\left(\mathrm{PAL} \sim 410 \mathrm{ppm} \mathrm{CO}_{2}\right.$ ) or rubber stoppers $\left(\mathrm{rO}_{2} \mathrm{eCO}_{2}\right)$, the latter gassed daily a premixed gas of 600 ppm $\mathrm{O}_{2}$ and $1000 \mathrm{ppm} \mathrm{CO}_{2}$ with the rest composed of $\mathrm{N}_{2}$ gas, at a flow rate of $0.5 \mathrm{~L} \mathrm{~min}{ }^{-1}$ for 15 minutes, and incubated as above.

Samples for photosynthesis were harvested on day 14 (late exponential/early stationary phase) in their appropriate atmospheres, and filtered onto a mixed cellulose filter of $3.0 \mu \mathrm{m}$ (Millipore SWPP02500, Germany). Filters were maintained on fresh moist agar plates at the appropriate atmosphere until NP assessment. The filters were placed in a sample lichen cuvette of the GFS3000 (WALZ, Germany) and the NP was determined over a range of light intensities. After the material was used for NP determinations, the filters were placed in a $2 \mathrm{ml}$ brown plastic vial to which 100 mg $0.1 \mathrm{~mm}$ Silica beads and $1.5 \mathrm{ml}$ 90\% neutralized methanol were added. Samples were bead beaten (Retsch) at 35 beats per second for 45 seconds and stored overnight at $4^{\circ} \mathrm{C}$. The following morning samples were vortexed and centrifuged for $15 \mathrm{~min}$ at $10000 \mathrm{~g}$. The absorbance of the cleared supernatant was as measured at $665 \mathrm{~nm}$ against a blank of $90 \%$ neutralized method and the chlorophyll a content determined (Meeks \& Castenholz, 1972). NP was expressed per $\mu \mathrm{g}$ Chl a.

Media was assessed for dissolved Ci using the program CO2SYS, version 2.3 (Lewis et al., 1998) with the experimentally determined values for $\mathrm{pH}$ and total alkalinity (TA) as input data. TA was measured using the open-cell titration method described in Dickson et al. (2007). The titration was conducted manually with a $10 \mathrm{ml}$ burette (Schott AG, Germany) and recorded with the pH meter model PHM210 (HyXo Oy, Finnland) with a SJ223 pH electrode (VWR, USA) which was also used to determine the input $\mathrm{pH}$ after incubation. For the TA calculation the program RStudio version 1.0.153 with the package seacarb was used. The phosphorus content of the samples was assessed photometrically as phosphomolybdenum blue (McKelvie et al., 1995) 


\section{Pigment determinations}

Prior to NP determinations, $4 \mathrm{ml}$ of culture was pelleted in each of 2 brown $2 \mathrm{ml}$ centrifuge tubes (repeated centrifugation) and used to determine the chlorophyll a or phycobiliprotein content per $\mathrm{ml}$ of culture. Chlorophyll determinations proceeded as above. Phycobilliproteins were extracted using $1.5 \mathrm{ml}$ of $0.1 \mathrm{M}$ potassium phosphate buffer $\mathrm{pH}$ 6.8, bead beating and 2 cycles of rapid freeze thawing in liquid nitrogen. Both pigment extractions were left overnight at $4^{\circ} \mathrm{C}$ before vortexing and centrifugation (15 min at $10000 \mathrm{~g}$ ). Chlorophyll a extractions were measured as above. The total phycobilliprotein content was determined from the absorption readings at 562, 615 and $652 \mathrm{~nm}$ (Bennett \& Bogorad, 1971, Bennett \& Bogorad, 1973).

\section{Pseudomat experiment:}

Late stationary phase cultures were concentrated, drained and used to inoculate sterilized sand (0.4-0.6mm washed aquarium sand baked at $200^{\circ} \mathrm{C}$ for 10 hours) in deep petri dishes in one of the three media representing the fresh, brackish and sea conditions mentioned above. Plates were placed into airtight culture containers and gassed daily as above, or left open for PAL controls. Plates were assessed for $\mathrm{O}_{2}$ production and redox levels after 13-15 days representing the early stationary phase in a glove box gassed with the matching culture atmosphere. Microsensors were calibrated according to the manufacturer's instructions (UNISENSE, Aarhus, Denmark) and programmed to take readings in $50 \mu \mathrm{m}$ increments from the surface to $6 \mathrm{~mm}$ beneath the surface. Each plate was measured 3-5 times depending on mat density.

\section{Gene screen}

The genetic potential of G. violaceus PCC7421 (Hagemann, 2013) and C. thermalis PCC7203 to synthesise compatible solutes to withstand increased salt stress was determined using BLAST to identify known genes associated with salinity tolerance (Kolman \& Salerno, 2015; Hagemann, 2013). In order to benefit from elevated $\mathrm{CO}_{2}$, cyanobacteria require a specialised transporter complement. The genomes of $G$. violaceus PCC7421 and C. thermalis PCC7203 were screened for the presence of 
$\mathrm{CO}_{2}$ and $\mathrm{HCO}_{3}^{-}$receptors (Visser et al., 2016) using BLAST (National Centre for Biotechnology Information, blast.ncbi.nlm.nih.gov).

\section{Statistics}

Statistical analyses were done using the two-tailed Student's t-test provided by Excel 2016 (Microsoft, USA) to determine the $\mathrm{rO}_{2} \mathrm{eCO}_{2}$ treatment influence and the effect of increasing salinities on the organisms' growth and $\mathrm{O}_{2}$ production.

\section{Results:}

\section{Growth curves}

The growth curves (Suppl. Fig. 1) indicate that both bacterial species grow better in freshwater analogous media, BG11. Interestingly, $C$. thermalis grew better when grown in ASNIII media than when grown in brackish media (BG11:ASNIII). G. violaceus was unable to grow in ASNIII media and this condition was therefore omitted in further experiments. Increasing salinity slows the overall increase in cell biomass. We decided to sample on days 13 - 15, late exponential/early stationary phase for both cultures, as the reproducibility was still good between culture replicates.

\section{Carbonate chemistry}

The increased availability of $\mathrm{Ci}$ in the media was confirmed by the carbonate chemistry. The pCO2 in control media was calculated to be in the range of $833 \pm 35$ $\mu$ atm for BG11, $1113 \pm 84 \mu$ atm for BG11:ASNIII and $844 \pm 67 \mu$ atm for ASNIII medium (Table 1). 
Table 1: Carbonate chemistry parameter for the control media after 14 days incubation under the appropriate atmosphere either measured or calculated using CO2SYS. Statistical significant differences between the two $\mathrm{CO}_{2}$ treatments are indicated by * for $\mathrm{p}<0.05$ (Student's t-test, twotailed). Abbreviations: $A_{T}$ total alkalinity, $C_{T}$ total carbon.

\begin{tabular}{|c|c|c|c|c|c|}
\hline $\begin{array}{l}\text { Growth } \\
\text { media } \\
\text { controls }\end{array}$ & $\mathrm{CO}_{2}$ treatment & $\begin{array}{l}\mathrm{pH} \\
\text { measured }\end{array}$ & $\begin{array}{l}\mathrm{A}_{\mathrm{T}} \\
\text { measured } \\
{[\mu \mathrm{mol} / \mathrm{kg}]}\end{array}$ & $\begin{array}{l}\mathrm{C}_{\mathrm{T}} \\
\text { calculated } \\
{[\mu \mathrm{mol} / \mathrm{kg}]}\end{array}$ & $\begin{array}{l}p \mathrm{CO}_{2} \\
\text { calculated } \\
{[\mu \mathrm{atm}]}\end{array}$ \\
\hline BG11 & PAL (380 ppm) & $7.98 \pm 0.03$ & $1502 \pm 37$ & $1195 \pm 32$ & $433 \pm 24$ \\
\hline BG11:ASNIII & PAL (380 ppm) & $7.50 \pm 0.01$ & $741 \pm 21$ & $543 \pm 15$ & $464 \pm 23$ \\
\hline ASNIII & PAL (380 ppm) & $7.32 \pm 0.01$ & $489 \pm 13$ & $346 \pm 9$ & $394 \pm 11$ \\
\hline BG11 & $\mathrm{eCO}_{2}(1000)$ & $7.71^{*} \pm 0.02$ & $1478 \pm 28$ & $1215 \pm 24$ & $833^{*} \pm 35$ \\
\hline BG11:ASNIII & $\mathrm{eCO}_{2}(1000)$ & $7.13^{*} \pm 0.02$ & $742 \pm 15$ & $576 \pm 27$ & $1113 * \pm 84$ \\
\hline ASNIII & $\mathrm{eCO}_{2}(1000)$ & $7.01 * \pm 0.01$ & $483 \pm 17$ & $373 \pm 19$ & $844^{*} \pm 67$ \\
\hline
\end{tabular}

\section{Salinity effects on total pigment content.}

Altering the salt content in media did not induce a significant change in the phycobilliprotein and chlorophyll a content of C. thermalis (Fig. 1A), however a significant reduction in carotenoid production was observed with increasing salinity. There was a significant drop in both phycobilliprotein and chlorophyll a content in cultures grown under $\mathrm{rO}_{2} \mathrm{eCO}_{2}$. Phycobilliprotein, chlorophyll a and carotenoid production was reduced for G. violaceus PCC7421 with increasing salinities and under the experimental atmosphere (Fig. 1B).

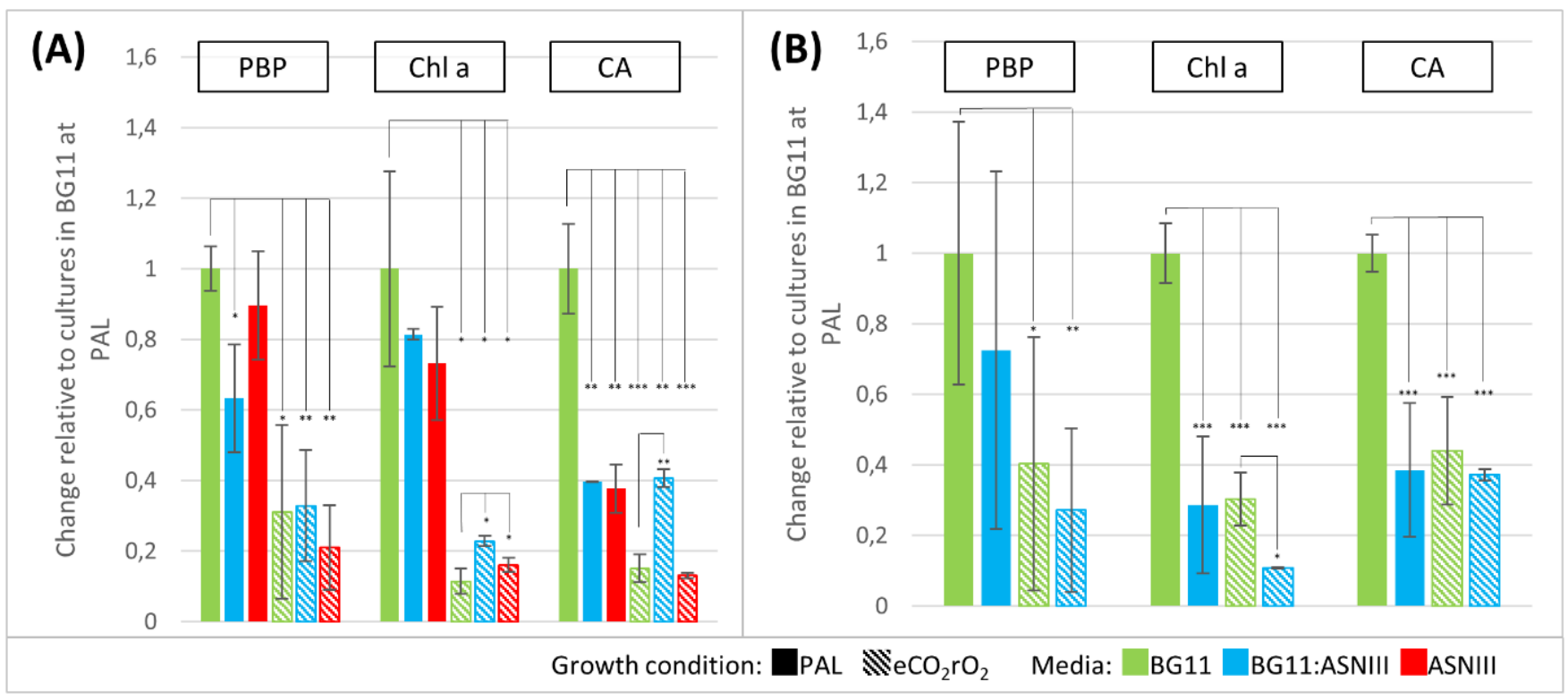


Figure 1: Phycobilliprotein (PBP), Chlorophyll a (Chl a) and Carotenoid (CA) content of 2 week old C. thermalis PCC7203 (A) and G. violaceus PCC7421 (B) cultures grown under different salinities and atmospheres. Pigment contend was photometrically determined in $\mu \mathrm{g}$ per $\mathrm{ml}$ culture from three independent samples and is expressed as relative value to respective cultures grown under $\mathrm{PAL}$ atmosphere in $\mathrm{BG} 11$ media $\pm \mathrm{SD}$. Cultures were incubated under PAL resp. $\mathrm{eCO}_{2} \mathrm{rO}_{2}$ atmosphere (solid / dashed colour) in media with increasing salinity levels from BG11 (fresh water, green) over BG11:ASNIII (brackish water, blue) to ASIII (sea water, red). Statistical significance values are indicated by ${ }^{*}$ for $p<0.05 ;{ }^{* *}$ for $p<0.01$ and ${ }^{* * *}$ for $p<0.001$ (Student's t-test, two-tailed).

\section{Salinity effects on nett photosynthesis}

Chroococidiopsis thermalis PCC7203 showed a significant decrease in nett photosynthesis rates expressed against chlorophyll a content, with increasing salinities (Fig. 2A) when cultured under PAL or $\mathrm{CO}_{2}$. What is interesting is the lack of decrease in NP per $\mu \mathrm{g}$ chlorophyll when grown under a $\mathrm{rO}_{2} \mathrm{eCO}_{2}$ atmosphere. When expressed per $\mathrm{ml}$ of culture medium (Fig.2C), the NP rates are significantly reduced for all cultures grown under $\mathrm{rO}_{2} \mathrm{eCO}_{2}$ atmosphere compared to measurements of cultures under PAL conditions in BG11. G. violaceus PCC7421, grown under PAL conditions, still showed comparative NP rates per $\mu \mathrm{g}$ chlorophyll $a$ to $C$. thermalis in BG11 medium (Fig. 2B). However, there was a significant decrease in NP when grown in brackish BG11:ASNIII medium or under $\mathrm{rO}_{2} \mathrm{eCO}_{2}$ atmosphere. Expressed as NP per ml culture (Fig.2D) cultures grown in BG:ASNIII showed a very significant decrease in $\mathrm{CO}_{2}$ assimilation compared to cultures in BG11 with NP close to zero if additionally incubated under a $\mathrm{rO}_{2} \mathrm{eCO}_{2}$ atmosphere. Additionally, no significant changes were observed in the dark respiration rates based on chlorophyll content (Suppl. Fig. 2). 
(A)

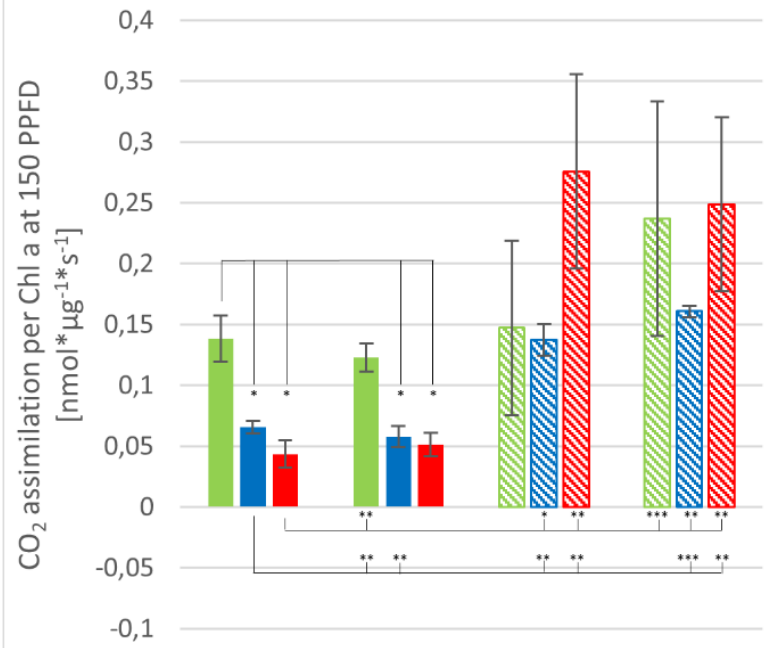

$\begin{array}{llll}\text { Measured at: PAL } & \mathrm{eCO}_{2} & \mathrm{eCO}_{2} & \mathrm{eCO}_{2} \mathrm{rO}_{2}\end{array}$
(B)

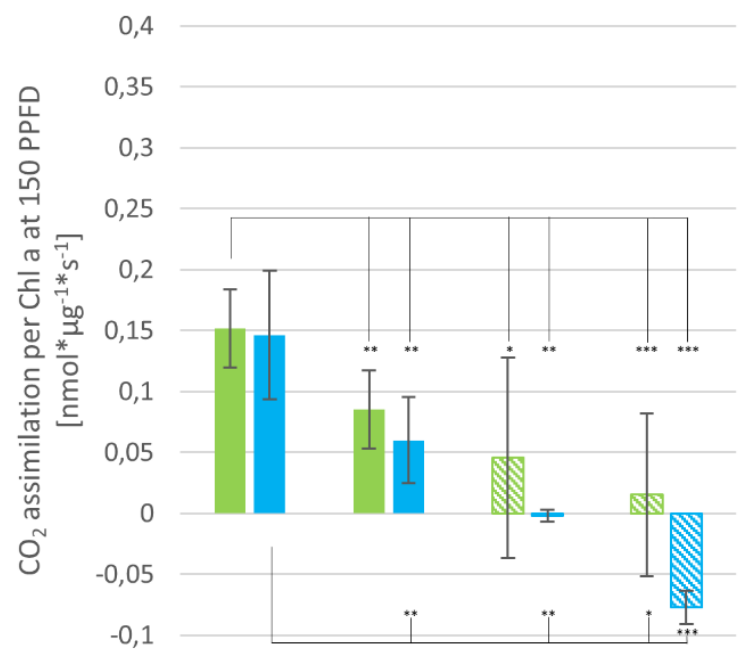

Measured at: PAL $\quad \mathrm{eCO}_{2} \mathrm{rO} \quad \mathrm{PAL} \quad \mathrm{eCO}_{2} \mathrm{rO}_{2}$

Growth condition: $\square$ PAL $\mathbb{N e C O}_{2} \mathrm{rO}_{2} \quad$ Media: $\quad$ BG11 $\square$ BG11:ASNIII —ASNIII

(C)

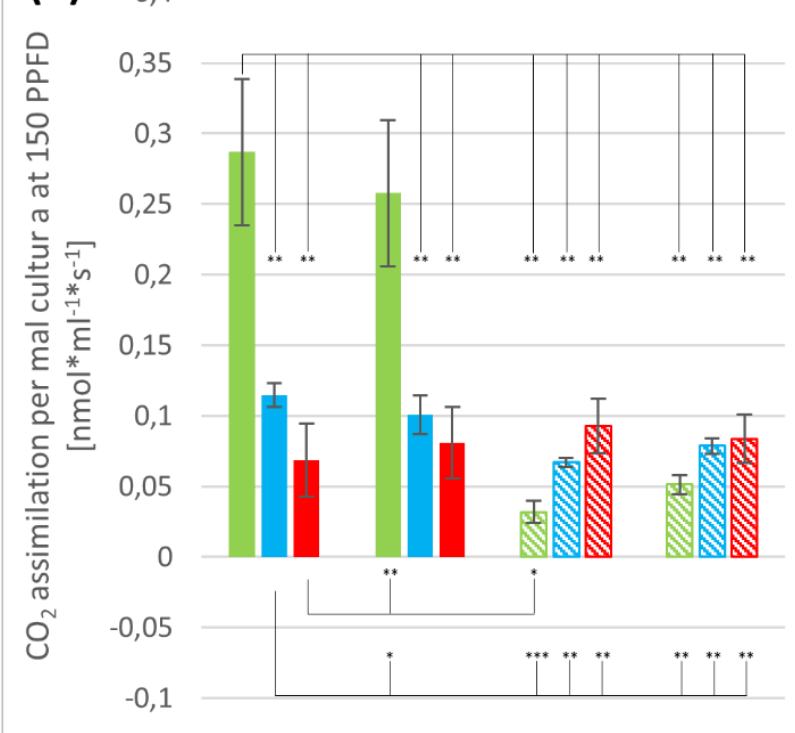

Measured at: PAL $\quad e_{2} \mathrm{CO}_{2} \mathrm{rO}_{2} \quad \mathrm{PAL} \quad \mathrm{eCO}_{2} \mathrm{rO}_{2}$
(D)

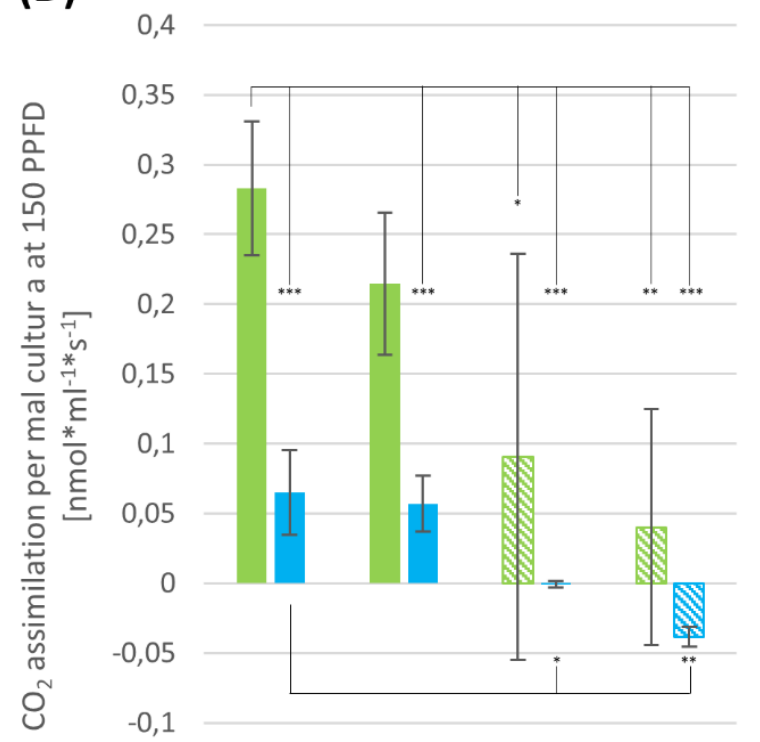

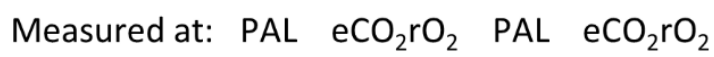

Growth condition: $\square$ PAL $\mathbb{N} \mathrm{NeO}_{2} \mathrm{rO}_{2} \quad$ Media: $\square$ BG11 —BG11:ASNIII —ASNIII

Figure 2: Representation of the nett photosynthesis of cultures grown under different salinities and atmospheres. The Nett photosynthesis of C. thermalis 7203 (A) and G. violaceus (B) are expressed as $\mathrm{CO} 2$ assimilation per second and $\mu \mathrm{g}$ Chlorophyl a, respectively per $\mathrm{ml}$ cultur (C) and (D). Cultures were incubated under PAL resp. $\mathrm{eCO}_{2} \mathrm{rO}_{2}$ atmosphere (solid / dashed colour) in media with increasing salinity levels from BG11 (fresh water, green) over BG11:ASNIII (brackish water, blue) to ASNIII (sea water, red). Statistical significance values are indicated by * for $p<0.05$; ${ }^{* *}$ for $p<0.01$ and ${ }^{\star * \star}$ for $p<0.001$ (Student's t-test, two-tailed). 


\section{Salinity effects on $\mathrm{O}_{2}$ production and redox levels in pseudomats.}

Microsensor readings indicated that we were indeed working under reduced $\mathrm{O}_{2}$ conditions, with readings approaching close to zero at $5 \mathrm{~mm}$ depth (Suppl. Fig. 4 B, D \& $E$ and Fig. $5 B$ \& D). Each of the triplicate pseudomat cultures were measured a minimum of 3 times generating 9 profiles per condition (Suppl. Figs $4 \& 5$ ). The $\mathrm{O}_{2}$ saturation point for media varies with changing salt content, therefore, the $\mathrm{O}_{2}$ saturation coming from the atmosphere is indicated as grey bar of the total value displayed in Fig. 3, with coloured readings indicating actual cyanobacterial $\mathrm{O}_{2}$ production. The $\mathrm{O}_{2}$ saturation points for the $\mathrm{rO}_{2} \mathrm{eCO}_{2}$ atmospheres were calculated as follows: $811 \mathrm{nmol} / \mathrm{L}$ (BG11), $727 \mathrm{nmol} / \mathrm{L}$ (BG11:ASNIII) and $642 \mathrm{nmol} / \mathrm{L}$ (ASNIII). The values are too small to graphically represent in Fig. 3.

C. thermalis PCC7203 exhibited a significant reduction in $\mathrm{O}_{2}$ production with increasing salinities under PAL conditions (Fig. 3), however there was still $\mathrm{O}_{2}$ production at higher salinity levels mimicking a marine environment. $\mathrm{O}_{2}$ release under a $\mathrm{rO}_{2} \mathrm{eCO}_{2}$ atmosphere was comparable to that under PAL for cultures growing in $\mathrm{BG} 11$. Increased medium salinity resulted in significant reduction of $\mathrm{O}_{2}$ production.

G. violaceus PCC7421 released comparable levels of $\mathrm{O}_{2}$ when grown in BG11 medium under both atmospheres tested (Fig. 3), but was significantly lower than recorded for $C$. thermalis PCC7203. Growing the pseudomats in brackish water significantly reduced the $\mathrm{O}_{2}$ release to the environment, however some $\mathrm{O}_{2}$ production was evident above the background within the first $5 \mathrm{~mm}$ under PAL conditions, with no $\mathrm{O}_{2}$ release observed under a $\mathrm{rO}_{2} \mathrm{eCO}_{2}$ atmosphere (Suppl. Fig. 4). 


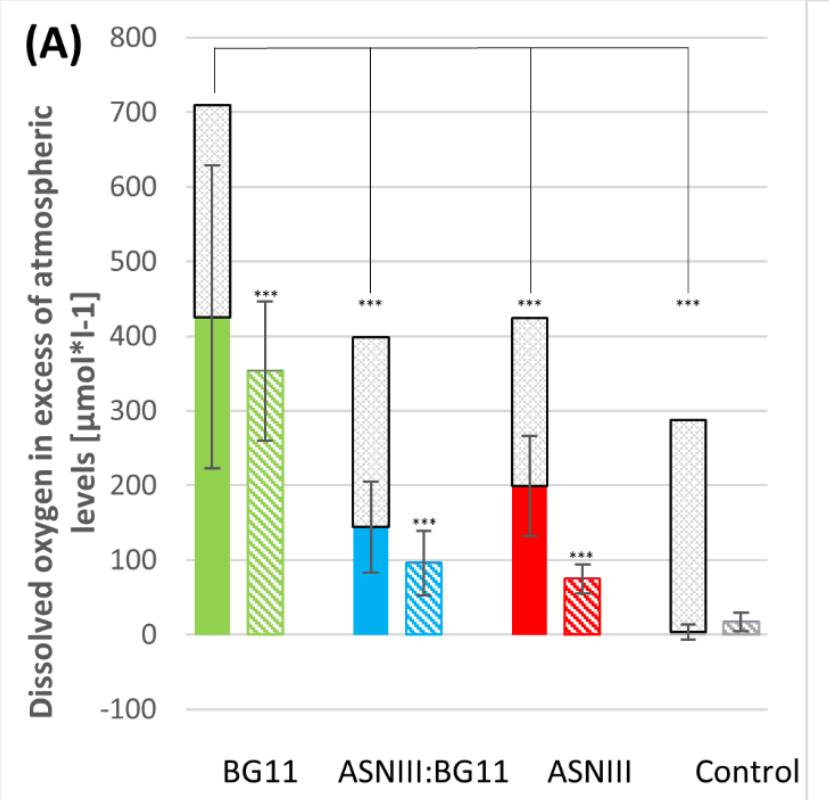

Max. Oxygen saturation in atmosphere
(B) 800

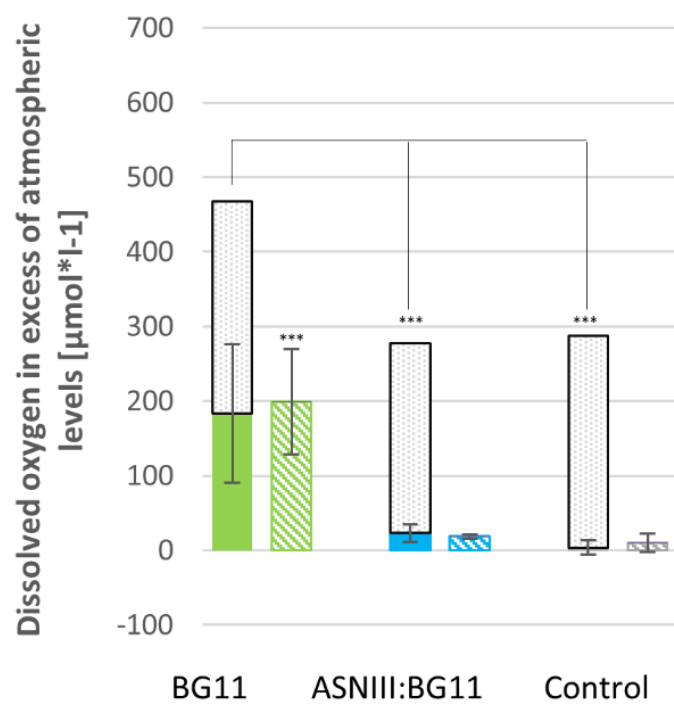

Growth condition: $\mathrm{PAL} \mathbb{N e C O} \mathrm{rO}_{2}$

Figure 3. $\mathrm{O}_{2}$ release for A: Chroococcidiopsis thermalis PCC7203 and B: Gloeobacter violaceus PCC7421. The bars represent the average of the top 9 readings for each pseudomat profile, with their standard deviations. Each bar represents a minimum of 9 profiles ( 3 profiles for each triplicate for each condition). The greyed out bar indicates the $\mathrm{O}_{2}$ saturation derived from exposure to the atmosphere for each of the media used. The control for BG11 is also included for comparison. Statistical significance was tested for increasing salinity and different atmospheres with the same media. Values are indicated by ${ }^{* * *}$ for $p<0.001$ (Student's t-test, two-tailed).

The overall reduction in redox potential of the environment with reduced $\mathrm{O}_{2}$. No real changes of redox values were observed in profiles through the pseudomats. The average of the top ten values are plotted below (Fig. 4) with those of the uninoculated control plates for comparison. The redox values recorded for $C$. thermalis PCC7203 grown under PAL conditions show a comparable increase for all three media tested, when compared to the redox readings obtained for the control uninoculated plates. No significant change in redox otential was observed for pseudomats grown under a $\mathrm{rO}_{2} \mathrm{eCO}_{2}$ atmosphere although the average reading was reduced in BG11 and BG11:ASNIII medium, suggesting an altered redox balance (Fig. 4). The redox readings for $G$. violaceus pseudomats grown under freshwater conditions were raised compared to control values, and equalled those observed for $C$. thermalis cultured in $\mathrm{BG} 11$ (Fig. 4). When grown under $\mathrm{rO}_{2} \mathrm{eCO}_{2}$, G. violaceus pseudomats showed lower average redox values than were recorded for the control media. 
(A) 250

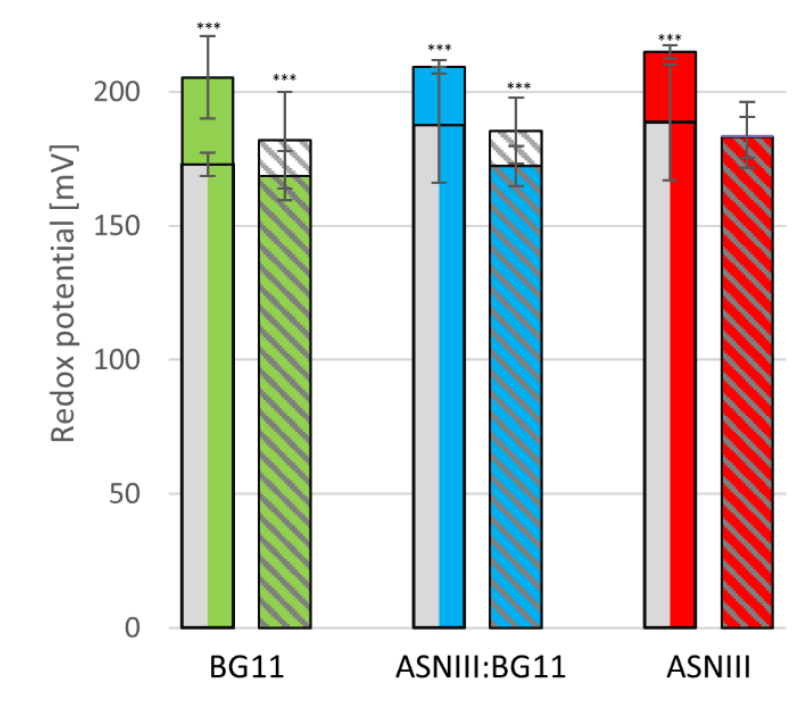

(B) 250

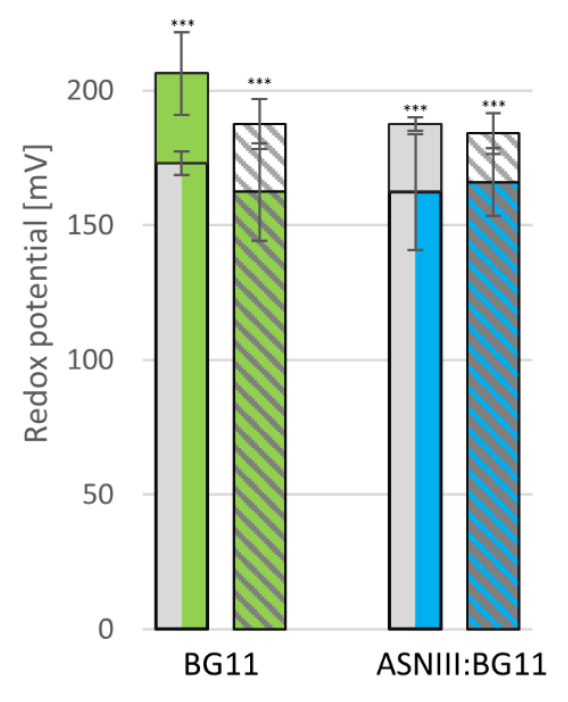

Growth condition: DPAL $: \mathrm{eCO}_{2} \mathrm{rO}_{2}$ Control

Figure 4: Redox potential profile for pseudomats of A: Chroococcidiopsis thermalis PCC7203 and B: Gloeobacter violaceus PCC7421. The coloured bars represent the average of the top 10 readings within the first $200 \mu \mathrm{m}$ for each pseudomat profile, with their standard deviations. Each bar represents a minimum of 9 profiles ( 3 profiles for each triplicate for each condition). The control values for each media are indicated as grey bars / grey dashed area. Statistical significance was tested between inoculated media and control. Values are indicated by *** for $p<0.001$ (Student's t-test, twotailed).

\section{Genetic acclimation potentential.}

Gloeobacter violaceus PCC 7421 was previously shown to carry the genes for sucrose-phosphate synthase (Hageman 2013). Our screen (Table 2) confirmed this and identified two additional $\mathrm{Na}^{+} / \mathrm{H}^{+}$antiporter receptors related to salt tolerance (Inaba et al., 2001) encoded on the genome of G. violaceus PCC7421. A screen of the $C$. thermalis PCC7203 genome revealed a similar salt tolerance gene profile with the addition of a high flux $\mathrm{Na}^{+} / \mathrm{H}^{+}$antiporter receptor and the genes for trehalose synthesis. The $\mathrm{C}_{\mathrm{i}}$ uptake receptor profile for both organisms indicates that they carry the genes for both gaseous $\mathrm{CO}_{2}$ uptake receptors and the 2 high specificity/low flux HCO3- receptors. Significantly, they also carry the gene encoding the low 
specificity/high flux receptor, BicA, conferring on both strains the ability to benefit from increased levels of $\mathrm{HCO}_{3}{ }^{-}$in the media resulting from elevated atmospheric $\mathrm{CO}_{2}$ levels.

Table 2: Gene screen results for $C$. thermalis $\mathrm{PCC} 7203$ and $G$. violaceus $\mathrm{PCC7421}$. The genomic sequences of both organisms were screened for the presence of genes conferring salt tolerance and the receptors involved in $\mathrm{C}_{i}$ uptake. The presence or absence of the gene is indicated by $a+$ or - for each genome and the gene description follows in the final column. Results marked with an ${ }^{1}$ are from (Kolman et al., 2015) and ${ }^{2}$ from Hageman et al., (2013). Details on tested sequences and E-values are described in Supply. Tab.1.

\begin{tabular}{|c|c|c|c|}
\hline Protein & $\begin{array}{l}\text { C. thermalis } \\
\text { PCC7203 }\end{array}$ & $\begin{array}{l}\text { G. violaceus } \\
\text { PCC7421 }\end{array}$ & Description \\
\hline SpsA & $+^{1}$ & $t^{2}$ & Sucrose-phosphate synthase \\
\hline Spp & $+^{1}$ & $t^{2}$ & Sucrose-phosphate phosphatase \\
\hline OtsAB & - & $2^{2}$ & $\begin{array}{l}\text { Trehalose-6-phosphate synthase/HAD } \\
\text { hydrolase }\end{array}$ \\
\hline Trez & + & $2^{2}$ & $\begin{array}{l}\text { Malto-oligosyltrehalose } \\
\text { trehalohydrolase }\end{array}$ \\
\hline TreY & + & $-^{2}$ & Malto-oligosyltrehalose synthase \\
\hline TreA & - & $-^{2}$ & Alpha,alpha-trehalase \\
\hline GgpS & - & $-^{2}$ & Glucosylglycerol-phosphate synthase \\
\hline GgpP & - & $-^{2}$ & Glucosylglycerol 3-phosphatase \\
\hline GpgS & - & $-^{2}$ & Glucosylglycerol phosphate synthase \\
\hline GgpgP & - & -2 & $\begin{array}{l}\text { Glucosyl-3-phosphoglycerate } \\
\text { phosphatase }\end{array}$ \\
\hline GsmT & - & $-^{2}$ & Glycine/sarcosine N-methyltransferase \\
\hline DmT & - & -2 & $\begin{array}{l}\text { Sarcosine/dimethylglycine } \mathrm{N} \text { - } \\
\text { methyltransferase }\end{array}$ \\
\hline NhaS1 & + & - & Low-affinity $\mathrm{Na}(+) / \mathrm{H}(+)$ antiporter \\
\hline NhaS3 & + & + & High-flux $\mathrm{Na}+\mathrm{H}+$ antiporter \\
\hline NhaS4 & + & + & $\mathrm{Na}+/ \mathrm{H}+$ antiporter \\
\hline
\end{tabular}




\begin{tabular}{|c|c|c|c|}
\hline Protein & $\begin{array}{l}\text { Chroococcidiopsis } \\
\text { thermalis PCC } 7203\end{array}$ & $\begin{array}{l}\text { Gloeobacter } \\
\text { violaceus PCC } 7421\end{array}$ & Description \\
\hline BicA & + & + & Low-affinity bicarbonate/sodium symporter \\
\hline SbtA & + & - & High-affinity bicarbonate/sodium symporter \\
\hline CmpA & + & + & $\begin{array}{l}\text { High-affinity ATP-dependent bicarbonate } \\
\text { uptake system }\end{array}$ \\
\hline CmpB & + & + & $\begin{array}{l}\text { High-affinity ATP-dependent bicarbonate } \\
\text { uptake system }\end{array}$ \\
\hline $\mathrm{CmpC}$ & + & + & $\begin{array}{l}\text { High-affinity ATP-dependent bicarbonate } \\
\text { uptake system }\end{array}$ \\
\hline CmpD & + & + & $\begin{array}{l}\text { High-affinity ATP-dependent bicarbonate } \\
\text { uptake system }\end{array}$ \\
\hline NadF3 & + & + & High-affinity $\mathrm{CO}_{2}$ uptake system \\
\hline NadhD3 & + & + & High-affinity $\mathrm{CO}_{2}$ uptake system \\
\hline NdhD4 & + & + & Low-affinity $\mathrm{CO}_{2}$ uptake system \\
\hline NdhF4 & + & + & Low-affinity $\mathrm{CO}_{2}$ uptake system \\
\hline ChpY & + & + & High-affinity $\mathrm{CO}_{2}$ uptake system \\
\hline ChpX & + & + & Low-affinity $\mathrm{CO}_{2}$ uptake system \\
\hline NahaS3 & + & + & Sodium/proton antiporter \\
\hline $\mathrm{CcmR2}$ & + & + & $\begin{array}{l}\text { Regulator of sodium-dependent bicarbonate } \\
\text { uptake operon }\end{array}$ \\
\hline $\mathrm{CcmR}$ & + & + & $\begin{array}{l}\text { Regulator of the high-affinity } \mathrm{CO}_{2} \text { uptake } \\
\text { operon }\end{array}$ \\
\hline
\end{tabular}

\section{Discussion}

Recently publications have provided evidence that oxidative photosynthesis, namely the splitting of water, evolved prior to the establishment of the oxidative phototrophs, cyanobacteria (Cardona, 2015, Cardona et al., 2015). This, combined with evolutionary studies indicating that the crown cyanobacteria evolved prior to the great oxygenation event in freshwater environments (Sanchez-Baracaldo, 2015, Sanchez- 
Baracaldo et al., 2017) has altered our understanding of how the world as we know it evolved: specifically regarding the conditions leading up to the GOE. First and foremost is the question of whether cyanobacteria could not just survive, but grow under increasing salinities to eventually give rise to the free ocean dwelling species thought to have precipitated the GOE 2.33 Ga. This study aimed to investigate the photosynthetic ability of the root cyanobacterial species, G. violaceus PCC7421 and a known salt tolerant ancient lineage cyanobacterium, C. thermalis PCC7203 to increasing salinities under present atmospheric conditions and those thought to have prevailed towards the end of the Archaean era.

C. thermalis PCC7203, while showing a significant decrease in overall NP activity with increasing salinities, was still able to grow and sequester $\mathrm{CO}_{2}$ when cultured in a PAL atmosphere (Fig. 2A \& C). G. violaceus PCC7421 significantly reduced its NP levels when grown in brackish medium under $\mathrm{PAL}$ atmospheric conditions (Fig 2B) and died in the sea salt analogous medium, ASNIII. While both organisms carried the genes for sucrose phosphate synthase, $C$. thermalis can potentially express genes for trehalose synthesis as well as an additional low affinity $\mathrm{Na}^{+} / \mathrm{H}^{+}$antiporter receptor (Table 2), thereby providing it with an additional potential mechanism to overcome salt stress.

Both organisms showed reduced levels of NP when grown under the $\mathrm{rO}_{2} \mathrm{eCO}_{2}$ atmosphere (Fig. 2 A \& B). Interestingly, the NP expressed per $\mu$ g chlorophyll $a$ or per $\mathrm{ml}$ of culture showed no reduction for $C$. thermalis with increasing salinity when compared to the fresh water control (Fig. 2C). The overall reduction in NP observed in cultures grown under the $\mathrm{rO}_{2} \mathrm{eCO}_{2}$ atmosphere is presumably the result of reduced pigment levels (Fig 1 A \& B). The presence of the low specificity / high flux $\mathrm{HCO}_{3}{ }^{-}$ receptor gene, bicA, would suggest that both strains should benefit from elevated $\mathrm{HCO}_{3}{ }^{-}$levels in the media resulting from $\mathrm{eCO}_{2}$ in the atmosphere (Visser et al., 2016). This was not observed in our study and may rest on several factors: $A$ ) the receptor is not expressed, $\mathrm{B}$ ) the reduced $\mathrm{O}_{2}$ levels restricted oxygen dependent pathways within the organisms, thereby restricting growth or $\mathrm{C}$ ) the $\mathrm{CO}_{2}$ was rapidly utilised in the closed system and the cells were Ci starved. While the control media incubated at the $\mathrm{rO}_{2} \mathrm{eCO}_{2}$ atmosphere contained elevated levels of $\mathrm{C}_{\mathrm{i}}$ (Table 1), the $\mathrm{C}_{\mathrm{i}}$ of the cell culture media was not determined. This is currently under investigation. 
While significant differences were observed for NP rates determined per $\mathrm{ml}$ of culture under the two different atmospheres, the $\mathrm{O}_{2}$ production rates appeared to be similar for each salinity tested (Fig 3), regardless off the atmosphere under which it was cultured. redox levels were increased in all cultures grown under PAL when compared to the control media, except for $G$. violaceus grown under brackish conditions (Fig. 4). In contrast, all cultures grown under the $\mathrm{rO}_{2} \mathrm{eCO}_{2}$ atmosphere showed redox values lower than the control media. This apparent reduction was however not significant.

While the exact nature of the $\mathrm{rO}_{2} \mathrm{eCO}_{2}$ increase in $\mathrm{Ci}$ availability in the cultures remains to be determined, we are still able to make some clear observations from this study. We have demonstrated that the fresh water strain of $C$. thermalis PCC7203 continues to fix $\mathrm{CO}_{2}$ at salinities representing brackish and sea salinities under PAL conditions. While its survival was previously demonstrated up to marine salinity of $250 \mathrm{mM} \mathrm{NaCl}$ (Cumbers \& Rothschild, 2014), the physiological effects of elevated salt on the process of oxidative photosynthesis had not been determined. Transfer of $C$. thermalis into brackish and sea salt media resulted in significant reduction in NP levels, presumably as the result of reduced pigment synthesis resulting from salt stress. G. violaceus in contrast was barely able to continue with NP in a brackish environment and not at all able to grow in marine analogous media (not shown). The additional genetic ability to synthesise trehalose presumably conferred upon $C$. thermalis an advantage to $G$. violaceaus, allowing it to grow in sea water.

Repeating this experiment under a $\mathrm{rO}_{2} \mathrm{eCO}_{2}$ atmosphere also showed that the two strains could continue photosynthesising in freshwater conditions, albeit at reduced levels compared to present levels of $\mathrm{CO}_{2}$ and $\mathrm{O}_{2}$ in the atmosphere. $C$. thermalis could also continue photosynthesising under increased salinities with comparable NP activities per $\mu \mathrm{g}$ chlorophyll $\mathrm{a}$ in this oxygen poor environment (Fig. 2). Overall biomass was reduced in the $\mathrm{rO}_{2} \mathrm{eCO}_{2}$ cultures as evidenced by the reduced pigment content per ml of culture (Fig. 1). The lack of increased respiration rates (Suppl. Fig. 2) and carotenoid synthesis (Fig. 1) suggests that even under increased salinities, the $C$. thermalis PCC7203 cultures were not overly stressed.

Taken together, this data supports the hypothesis of Cyanobacterial evolution in freshwater environments and their transition into increasingly salty environments 
(Sanchez-Baracaldo, 2015, Sanchez-Baracaldo et al., 2017) as illustrated in Fig. 5. Cyanobacteria originated in a freshwater environment which would also have allowed the formation of loose microbial mats on solid substrates along the edges of the water body. Occasional flooding events would have transferred cyanobacterial biomass along a downward gradient, allowing them to colonise potentially brackish environments, possibly in a delta scenario. Further flooding from either an ocean or wash out from inland freshwaters, could have introduced the originally freshwater strain into an ocean environment. By demonstrating active photosynthesis in both liquid cultures and pseudomats, we have shown that some cyanobacterial species, equipped with the minimal gene complement of sucrose and trehalose synthesis, would have been able to make the gradual transition into increasingly saline environments, not only in PAL atmospheric conditions, but under the reduced oxygen and elevated $\mathrm{CO}_{2}$ conditions thought to have existed during the late Archaean.

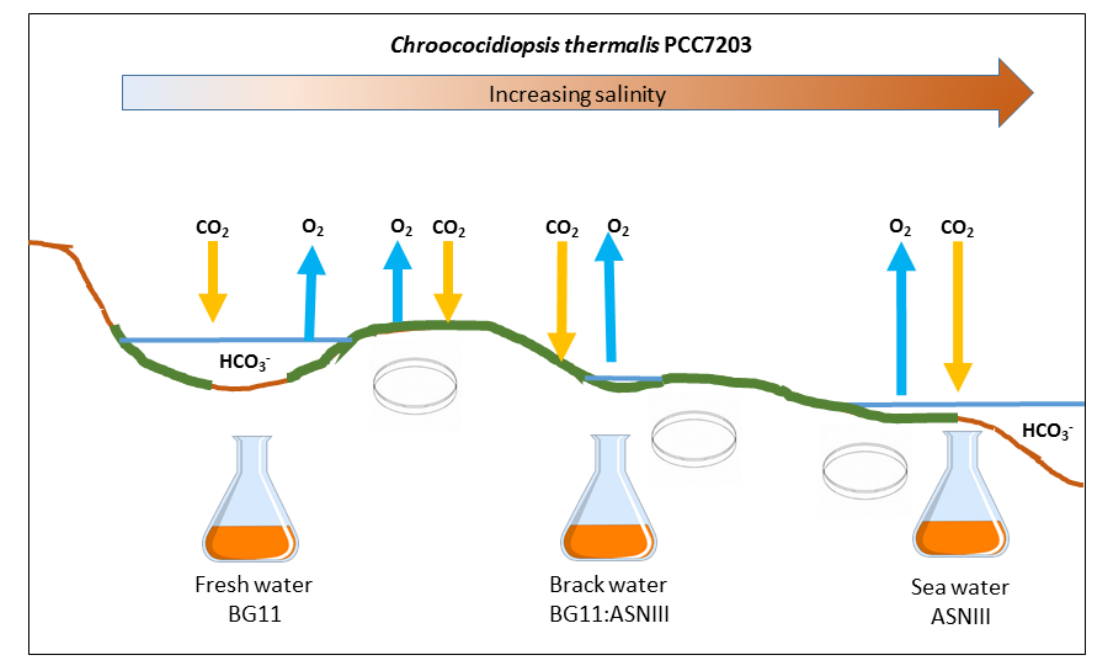

Figure 5: Graphical representation of the transfer of an ancestral freshwater cyanobacterial species through increasing salinities during the Archaean. Please see text for a complete explanation. $\mathrm{CO}_{2}$ with yellow arrow represents photosynthetic activity (measured by gas exchange in this study). $\mathrm{O} 2$ with a blue arrow represents the release of oxygen resulting from active photosynthesis (measured using $\mathrm{O}_{2}$ microsensors in this study). The flasks represent the liquid cultures and the plates represent the pseudomats used to assess cyanobacterial growth under increasing salinities from fresh, through brackish to marine strength salinity. 


\section{References}

Bahl J, Lau MC, Smith GJ, Vijaykrishna D, Cary SC, Lacap DC, Lee CK, Papke RT, Warren-Rhodes KA \& Wong FK (2011) Ancient origins determine global biogeography of hot and cold desert cyanobacteria. Nat Commun 2: 163.

Bennett A \& Bogorad L (1971) Properties of Subunits and Aggregates of Blue-Green Algal Biliproteins. Biochemistry-Us 10: 3625-\&.

Bennett A \& Bogorad L (1973) Complementary Chromatic Adaptation in a Filamentous Blue-GreenAlga. Journal of Cell Biology 58: 419-435.

Billi D, Viaggiu E, Cockell CS, Rabbow E, Horneck G \& Onofri S (2011) Damage Escape and Repair in Dried Chroococcidiopsis spp. from Hot and Cold Deserts Exposed to Simulated Space and Martian Conditions. Astrobiology 11: 65-73.

Büdel B, Colesie C, Green TA, Grube M, Suau RL, Loewen-Schneider K, Maier S, Peer T, Pintado A \& Raggio J (2014) Improved appreciation of the functioning and importance of biological soil crusts in Europe: the Soil Crust International Project (SCIN). Biodiversity and Conservation 1-20.

Budel B, Weber B, Kuhl M, Pfanz H, Sultemeyer D \& Wessels D (2004) Reshaping of sandstone surfaces by cryptoendolithic cyanobacteria: bioalkalization causes chemical weathering in arid landscapes. Geobiology 2: 261-268.

Cardona T (2015) A fresh look at the evolution and diversification of photochemical reaction centers. Photosynth Res 126: 111-134.

Cardona T, Murray JW \& Rutherford AW (2015) Origin and Evolution of Water Oxidation before the Last Common Ancestor of the Cyanobacteria. Molecular Biology and Evolution 32: 1310-1328.

Cockell CS, Rettberg P, Rabbow E \& Olsson-Francis K (2011) Exposure of phototrophs to 548 days in low Earth orbit: microbial selection pressures in outer space and on early earth. Isme J 5: 16711682.

Cumbers J \& Rothschild LJ (2014) Salt tolerance and polyphyly in the cyanobacterium Chroococcidiopsis (Pleurocapsales). J Phycol.

Djokic T, Van Kranendonk MJ, Campbell KA, Walter MR \& Ward CR (2017) Earliest signs of life on land preserved in ca. $3.5 \mathrm{Ga}$ hot spring deposits. Nat Commun 8.

Fewer D, Friedl T \& Büdel B (2002) Chroococcidiopsis and heterocyst-differentiating cyanobacteria are each other's closest living relatives. Molecular Phylogenetics and Evolution 23: 82-90.

Guglielmi G, Cohenbazire G \& Bryant DA (1981) The Structure of Gloeobacter-Violaceus and Its Phycobilisomes. Arch Microbiol 129: 181-189.

Hagemann M (2013) Genomics of Salt Acclimation: Synthesis of Compatible Solutes among Cyanobacteria. Adv Bot Res 65: 27-55.

Heubeck C, Blasing S, Grund M, Drabon N, Homann M \& Nabhan S (2016) Geological constraints on Archean (3.22 Ga) coastal -zone processes from the Dycedale Syncline, Barberton Greenstone Belt. S Afr J Geol 119: 495-518.

Homann M, Heubeck C, Bontognali TRR, Bouvier AS, Baumgartner LP \& Airo A (2016) Evidence for cavity-dwelling microbial life in 3.22 Ga tidal deposits. Geology 44: 51-54.

Kolman, M.A.; Nishi, C.N.; Perez-Cenci, M.; Salerno, G.L. Sucrose in Cyanobacteria: From a SaltResponse Molecule to Play a Key Role in Nitrogen Fixation. Life 2015, 5, 102-126.

Lenton TM \& Daines SJ (2017) Matworld - the biogeochemical effects of early life on land. New Phytologist 215: 531-537.

Sanchez-Baracaldo P (2015) Origin of marine planktonic cyanobacteria. Sci Rep-Uk 5.

Sanchez-Baracaldo P, Raven JA, Pisani D \& Knoll AH (2017) Early photosynthetic eukaryotes inhabited low-salinity habitats. P Natl Acad Sci USA 114: E7737-E7745.

Sánchez-Baracaldo P, Ridgwell A \& Raven JA (2014) A Neoproterozoic transition in the marine nitrogen cycle. Current Biology 24: 652-657.

Saw JHW, Schatz M, Brown MV, Kunkel DD, Foster JS, Shick H, Christensen S, Hou SB, Wan XH \& Donachie SP (2013) Cultivation and Complete Genome Sequencing of Gloeobacter kilaueensis sp nov., from a Lava Cave in Kilauea Caldera, Hawai'i. Plos One 8. 
Stueken EE, Buick R \& Schauer AJ (2015) Nitrogen isotope evidence for alkaline lakes on late Archean continents. Earth Planet Sc Lett 411: 1-10.

Visser PM, Verspagen JMH, Sandrini G, Stal L, Matthijs HCP, Davis TW, Paerl HW \& Huisman J (2016) How rising $\mathrm{CO} 2$ and global warming may stimulate harmful cyanobacterial blooms. Harmful Algae 54: 145-159.

\section{Supplementary data}
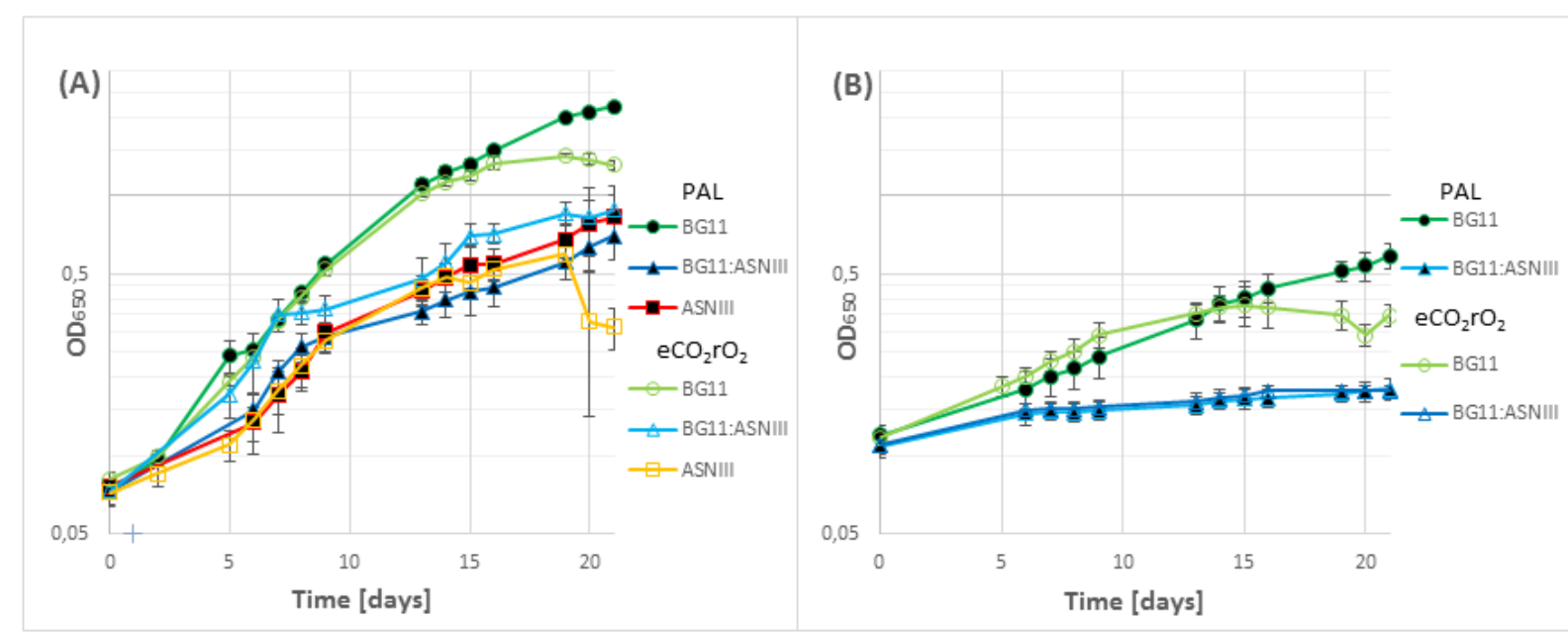

Supplementary Figure 1: Cyanobacterial growth curves under increasing salinities for A:

Chroococcidiopsis thermalis PCC7203 and B: Gloeobacter violaceus PCC7421. All cultures were exposed to a PAL atmosphere for 5-10 minutes at every absorbance reading. 


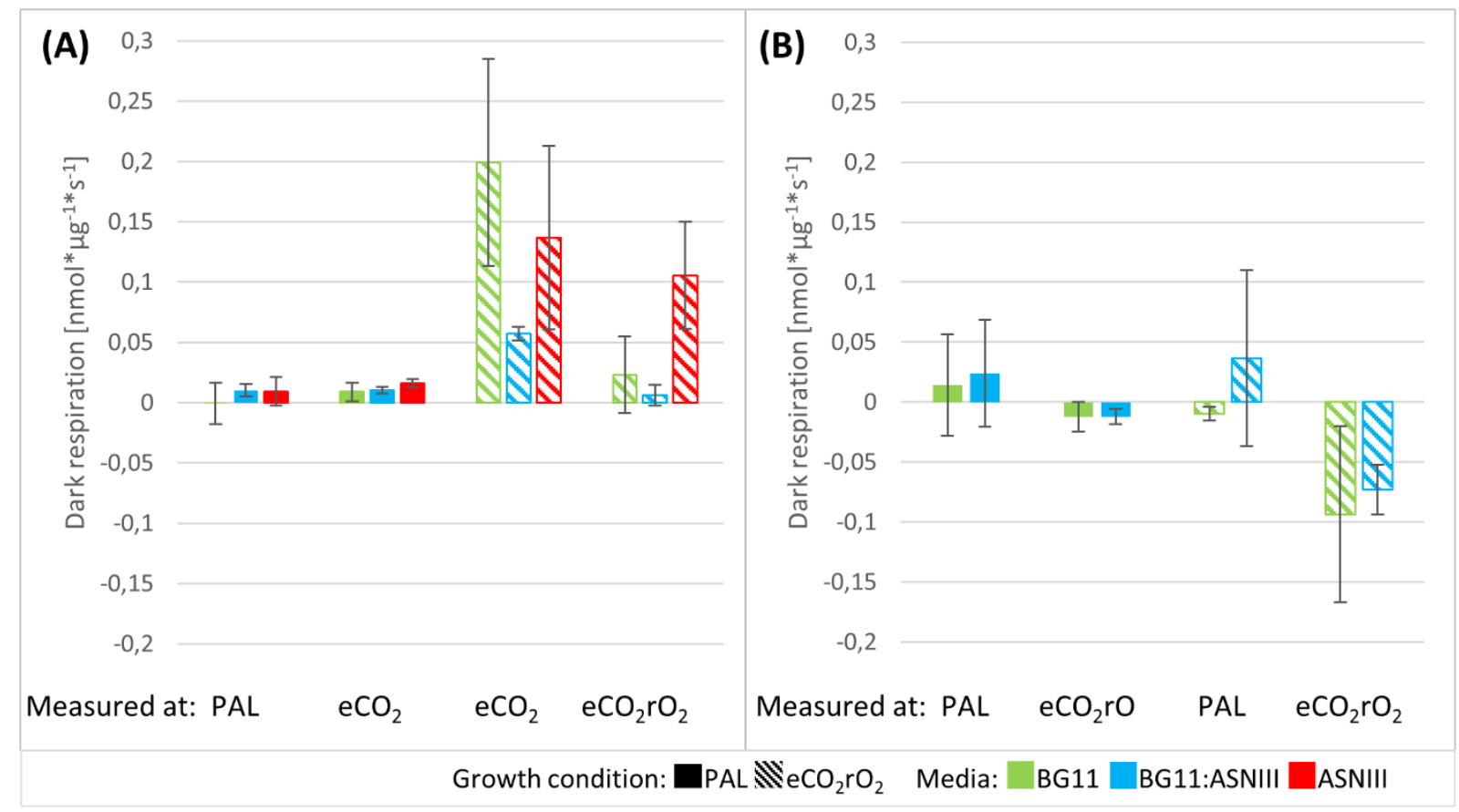

Supplementary Figure 2: Representation of the dark respiration rates of cultures grown under different salinities and atmospheres. Respiration rates expressed for chlorophyll a content of $C$. thermalis 7203 (A) and G. violaceus (B) with increasing salinities and $\mathrm{rO}_{2} \mathrm{eCO}_{2}$ conditions. G. violaceus cultures grown under PAL conditions and in freshwater were also assessed for their NP under $\mathrm{eCO}_{2} \mathrm{rO}_{2}$. 


\section{(A)}

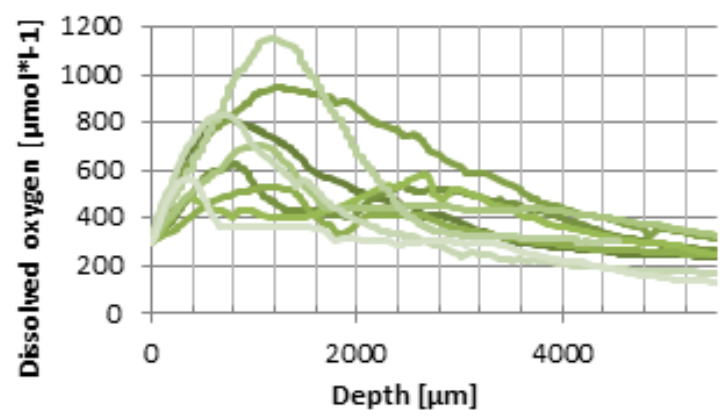

(C)

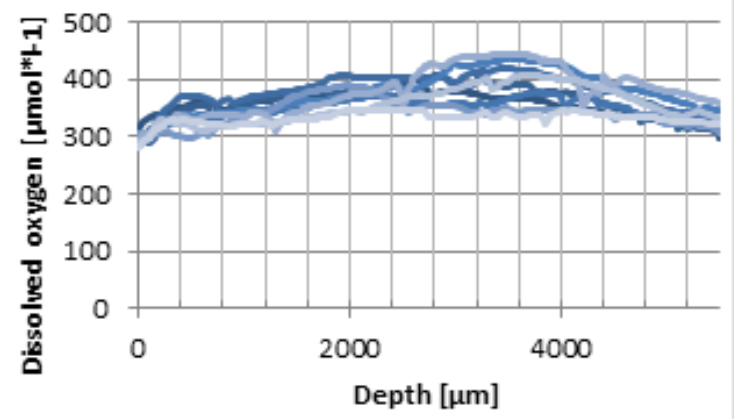

(E)

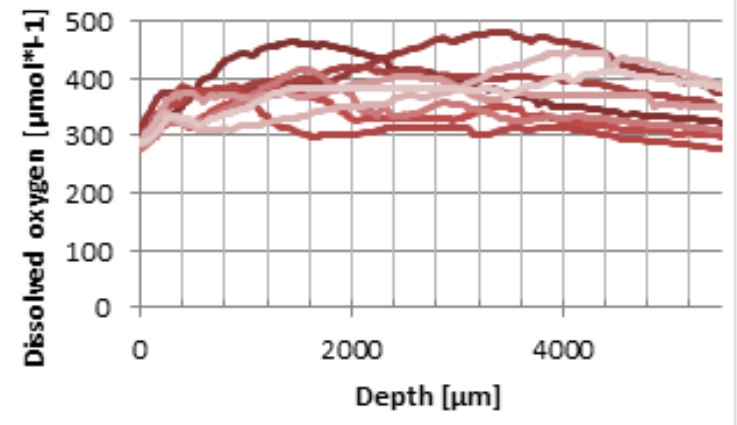

(B) $\mathrm{eCO}_{2} \mathrm{rO}_{2}$

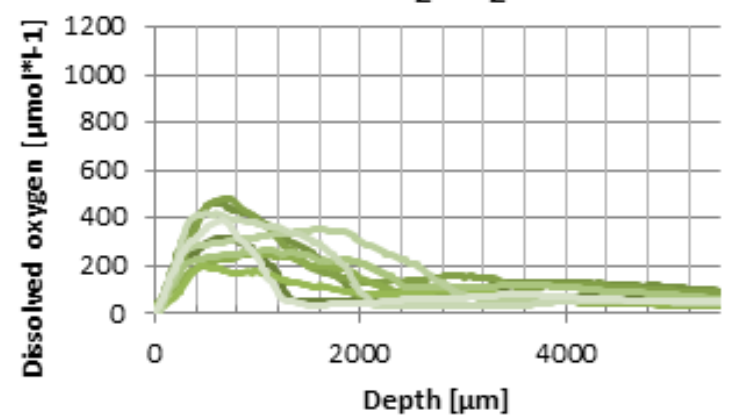

(D)

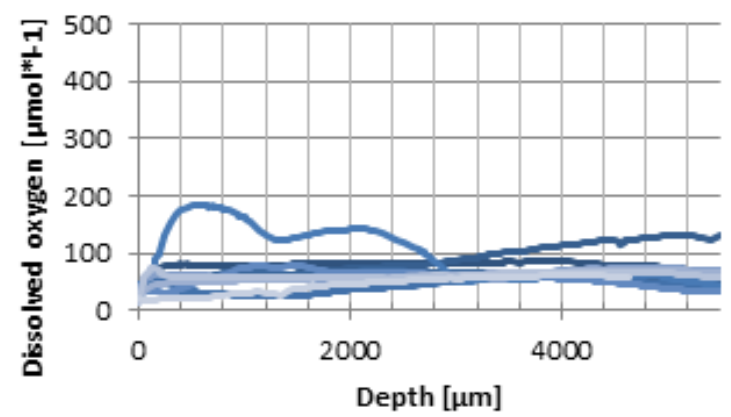

(F)

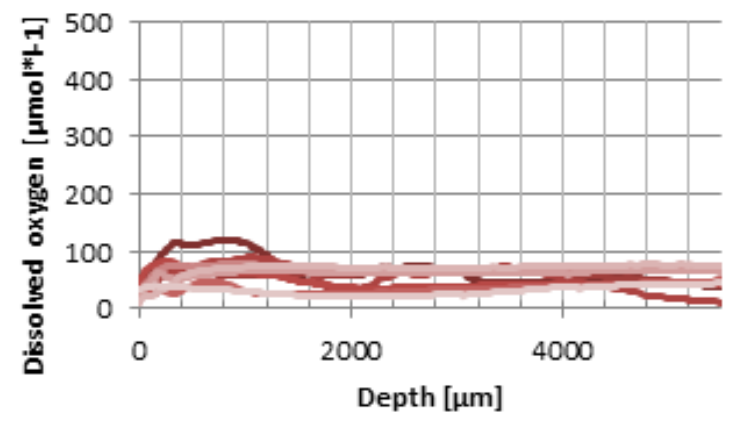

Supplementary Figure 3: Dissolved oxygen measured in pseudomats of Chroococcidiopsis thermalis PCC7203. A, C, E, are grown under PAL conditions while B, D and F are grown under $\mathrm{rO}_{2} \mathrm{eCO}_{2}$. Pseudomats $A \& B$ are grown in freshwater analogous medium BG11, C \& D in brackish analogous medium BG11:ASNIII while E \& F represent pseudomats grown in sea water analogous medium ASNIII. First surface contact was determined as readings over or under atmospheric levels. 


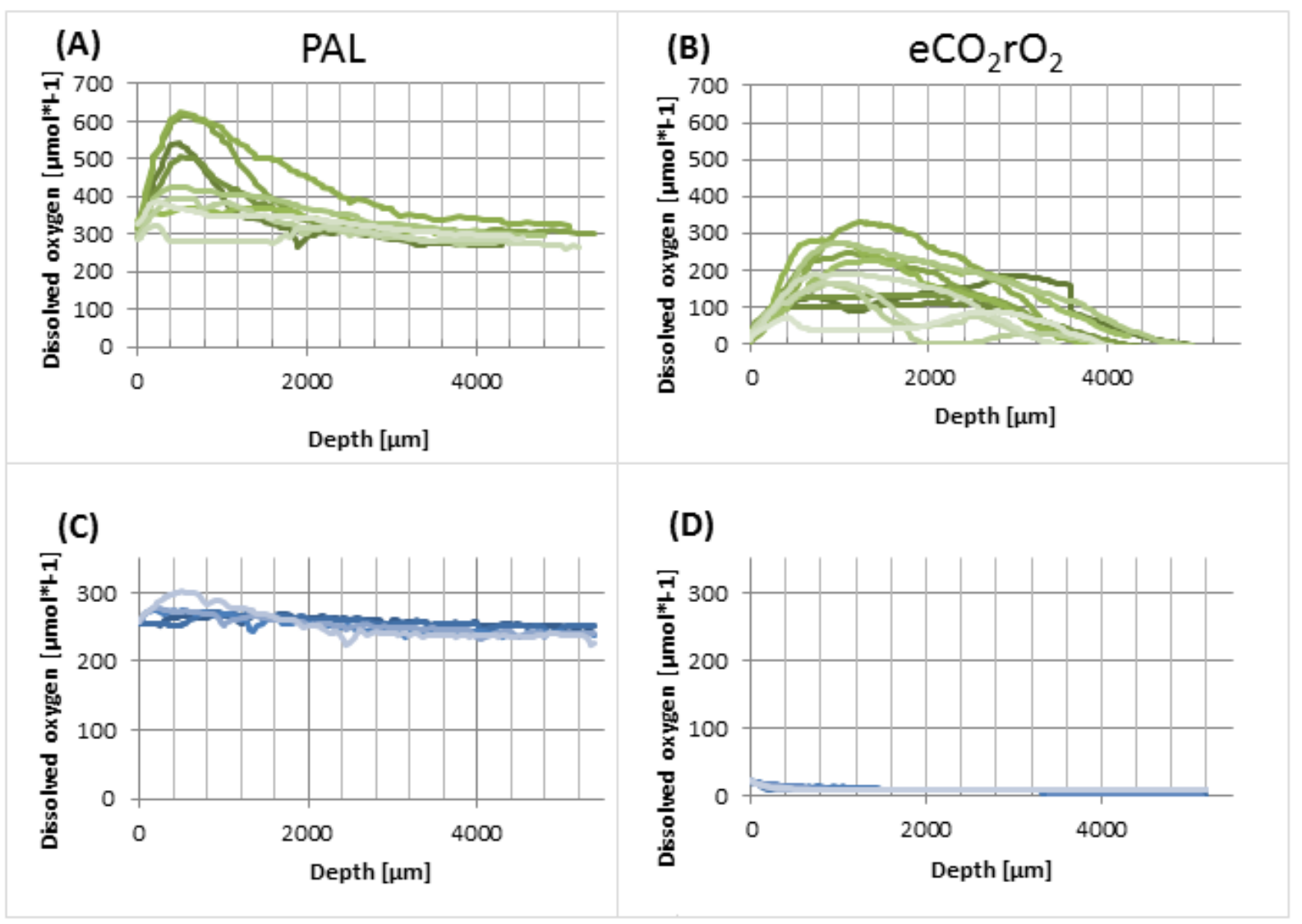

Supplementary Figure 4: Dissolved oxygen measured in pseudomats of Gloeobacter violaceus PCC7421. A \&C are grown under PAL conditions while $B \& D$ are grown under $\mathrm{rO}_{2} \mathrm{eCO}_{2}$. Pseudomats $A \& B$ are grown in freshwater analogous medium $B G 11$, while $C \& D$ represent pseudomats grown in brackish analogous medium BG11:ASNIII. 


\section{Supplementary Table 1: Gene screen results for $C$. thermalis PCC7203 and G. violaceus}

PCC7421. The genomic sequences of both organisms were screened for the presence of genes conferring salt tolerance and the receptors involved in $C_{i}$ uptake. The gene ID and name used for the screen is listed under the Protein column. High E-values, indicating a random hit, or no matches at all are marked in red.

\begin{tabular}{|c|c|c|c|c|c|c|}
\hline \multirow[b]{2}{*}{ Name } & \multicolumn{2}{|c|}{ Query Sequence } & \multicolumn{2}{|c|}{$\begin{array}{c}\text { Chroococcidiopsis thermalis } \\
\text { PCC } 7203\end{array}$} & \multicolumn{2}{|c|}{$\begin{array}{c}\text { Gloeobacter violaceus PCC } \\
7421\end{array}$} \\
\hline & Locus & Organism & Locus & E-value & Locus & E-value \\
\hline OtsAB & AFE09714.1 & $\begin{array}{l}\text { Corallococcus } \\
\text { coralloides }\end{array}$ & - & & & \\
\hline TreZ & $\begin{array}{l}\text { WP_010994 } \\
345 \\
\text { WP } 010994\end{array}$ & Nostoc sp. PCC 7120 & $\begin{array}{l}\text { WP_01515358 } \\
4.1 \\
\text { WP } 01515358\end{array}$ & 0 & & \\
\hline TreY & 344 & Nostoc sp. PCC 7120 & $3.1^{-}$ & 0 & & \\
\hline TreA & $\begin{array}{l}\text { WP_010994 } \\
343\end{array}$ & Nostoc sp. PCC 7120 & - & $5.0 \mathrm{E}-04$ & & \\
\hline GgpS & P74258.1 & $\begin{array}{l}\text { Synechocystis sp. } \\
\text { PCC } 6803 \\
\text { Synechocystis sp. }\end{array}$ & - & 0,055 & & \\
\hline GgpP & $\begin{array}{l}\text { Q55034.1 } \\
\text { ACB00008 }\end{array}$ & $\begin{array}{l}\text { PCC } 6803 \\
\text { Synechococcus sp. }\end{array}$ & - & 0,17 & & \\
\hline GpgS & COQRP9 & $\begin{array}{l}\text { PCC } 7002 \\
\text { Persephonella marina }\end{array}$ & - & 7 & & \\
\hline $\begin{array}{l}\text { GgpgP } \\
\text { GsmT }\end{array}$ & Q7U4Z8 & $\begin{array}{l}\text { EX-H1 } \\
\text { Synechococcus sp. } \\
\text { WH } 8102\end{array}$ & - & $\begin{array}{l}1,3 \\
3.0 \mathrm{E}-07\end{array}$ & & \\
\hline DmT & Q83WC3 & $\begin{array}{l}\text { Aphanothece } \\
\text { halophytica }\end{array}$ & - & $4.0 \mathrm{E}-17$ & & \\
\hline NhaS1 & $\begin{array}{l}\text { WP_010872 } \\
552\end{array}$ & $\begin{array}{l}\text { Synechocystis sp. } \\
\text { PCC } 6803\end{array}$ & $\begin{array}{l}\text { WP_04146257 } \\
2.1\end{array}$ & $3.0 \mathrm{E}-117$ & & \\
\hline NhaS3 & $\begin{array}{l}\text { WP_012307 } \\
968\end{array}$ & $\begin{array}{l}\text { Synechocystis } \\
\text { PCC } 6803\end{array}$ & $\begin{array}{l}\text { WP_01515381 } \\
5.1\end{array}$ & 0 & $\begin{array}{l}\text { WP_011140814. } \\
1\end{array}$ & \\
\hline NhaS4 & $\begin{array}{l}\text { WP_010871 } \\
619\end{array}$ & $\begin{array}{l}\text { Synechocystis } \\
\text { PCC } 6803\end{array}$ & $\begin{array}{l}\text { WP_01515475 } \\
3.1\end{array}$ & $2.0 \mathrm{E}-152$ & $\begin{array}{l}\text { WP_015154753. } \\
1\end{array}$ & 0.002 \\
\hline & & & & & & $\begin{array}{l}3.0 \mathrm{E}-96 \\
4.0 \mathrm{E}-128\end{array}$ \\
\hline
\end{tabular}

\begin{tabular}{|c|c|c|c|c|c|c|}
\hline \multicolumn{3}{|c|}{ Query Sequence } & \multicolumn{2}{|c|}{$\begin{array}{c}\text { Chroococcidiopsis thermalis } \\
\text { PCC } 7203\end{array}$} & \multicolumn{2}{|c|}{$\begin{array}{c}\text { Gloeobacter violaceus PCC } \\
7421\end{array}$} \\
\hline Name & Locus & Organism & Locus & E-value & Locus & E-value \\
\hline BicA & AHJ28514.1 & $\begin{array}{l}\text { Nodularia spumigena } \\
\text { CCY9414 }\end{array}$ & $\begin{array}{l}\text { WP_015153132 } \\
.1\end{array}$ & 0 & $\begin{array}{l}\text { WP_011143678 } \\
.1\end{array}$ & $9.00 \mathrm{E}-66$ \\
\hline SbtA & BAG06031 & $\begin{array}{l}\text { Microcystis aeruginosa } \\
\text { PCC } 7806\end{array}$ & $\begin{array}{l}\text { WP_015153813 } \\
.1\end{array}$ & 0 & - & \\
\hline CmpA & BAG01821.1 & $\begin{array}{l}\text { Microcystis aeruginosa } \\
\text { PCC } 7806\end{array}$ & $\begin{array}{l}\text { WP_015152989 } \\
.1\end{array}$ & $2.0 \mathrm{E}-63$ & $\begin{array}{l}\text { WP_011141566 } \\
.1\end{array}$ & $4.0 \mathrm{E}-134$ \\
\hline $\mathrm{CmpB}$ & BAG01822.1 & $\begin{array}{l}\text { Microcystis aeruginosa } \\
\text { PCC } 7806\end{array}$ & $\begin{array}{l}\text { WP_015152990 } \\
.1\end{array}$ & 8.0E-121 & $\begin{array}{l}\text { WP_011142085 } \\
.1\end{array}$ & 3.0E-94 \\
\hline
\end{tabular}




\begin{tabular}{|c|c|c|c|c|c|c|}
\hline $\mathrm{CmpC}$ & BAG01823.1 & $\begin{array}{l}\text { Microcystis aeruginosa } \\
\text { PCC } 7806\end{array}$ & $\begin{array}{l}\text { WP_015152991 } \\
.1\end{array}$ & 0 & $\begin{array}{l}\text { WP_011142087 } \\
.1\end{array}$ & 0 \\
\hline CmpD & BAG01824.1 & $\begin{array}{l}\text { Microcystis aeruginosa } \\
\text { PCC } 7806\end{array}$ & $\begin{array}{l}\text { WP_015152992 } \\
.1\end{array}$ & 1.0E-163 & $\begin{array}{l}\text { WP_011142088 } \\
.1\end{array}$ & 7.0E-140 \\
\hline NadF3 & BAG01334.1 & $\begin{array}{l}\text { Microcystis aeruginosa } \\
\text { PCC } 7806\end{array}$ & $\begin{array}{l}\text { WP_015152167 } \\
.1\end{array}$ & 0 & $\begin{array}{l}\text { WP_011141005 } \\
.1\end{array}$ & 0 \\
\hline NadhD3 & BAG01336.1 & $\begin{array}{l}\text { Microcystis aeruginosa } \\
\text { PCC } 7806\end{array}$ & $\begin{array}{l}\text { WP_015152168 } \\
.1\end{array}$ & 0 & $\begin{array}{l}\text { WP_011141006 } \\
.1\end{array}$ & 0 \\
\hline NdhD4 & BAG05662.1 & $\begin{array}{l}\text { Microcystis aeruginosa } \\
\text { PCC } 7806\end{array}$ & $\begin{array}{l}\text { WP_015153094 } \\
.1\end{array}$ & 0 & $\begin{array}{l}\text { WP_011142080 } \\
.1\end{array}$ & 0 \\
\hline NdhF4 & BAG02551.1 & $\begin{array}{l}\text { Microcystis aeruginosa } \\
\text { PCC } 7806\end{array}$ & $\begin{array}{l}\text { WP_015153093 } \\
.1\end{array}$ & 0 & $\begin{array}{l}\text { WP_011142081 } \\
.1\end{array}$ & 0 \\
\hline ChpY & BAG01338.1 & $\begin{array}{l}\text { Microcystis aeruginosa } \\
\text { PCC } 7806\end{array}$ & $\begin{array}{l}\text { WP_015152169 } \\
.1\end{array}$ & 0 & $\begin{array}{l}\text { WP_011141007 } \\
.1\end{array}$ & 0 \\
\hline ChpX & BAG03399.1 & $\begin{array}{l}\text { Microcystis aeruginosa } \\
\text { PCC } 7806\end{array}$ & $\begin{array}{l}\text { WP_015153095 } \\
.1\end{array}$ & 0 & $\begin{array}{l}\text { WP_011142079 } \\
.1\end{array}$ & $2.0 \mathrm{E}-173$ \\
\hline NahaS3 & CA090187.1 & $\begin{array}{l}\text { Microcystis aeruginosa } \\
\text { PCC } 7806\end{array}$ & $\begin{array}{l}\text { WP_015153815 } \\
.1\end{array}$ & 0 & $\begin{array}{l}\text { WP_011140517 } \\
.1\end{array}$ & $1.0 \mathrm{E}-100$ \\
\hline CcmR2 & $\begin{array}{l}\text { WP_041804 } \\
464.1\end{array}$ & $\begin{array}{l}\text { Microcystis aeruginosa } \\
\text { PCC } 7806\end{array}$ & $\begin{array}{l}\text { WP_015153086 } \\
.1\end{array}$ & 0 & $\begin{array}{l}\text { WP_011141003 } \\
.1\end{array}$ & 3.0E-100 \\
\hline $\mathrm{CcmR}$ & $\begin{array}{l}\text { WP_012268 } \\
320.1\end{array}$ & $\begin{array}{l}\text { Microcystis aeruginosa } \\
\text { NIES-843 }\end{array}$ & $\begin{array}{l}\text { WP_015153086 } \\
.1\end{array}$ & $2.0 \mathrm{E}-138$ & $\begin{array}{l}\text { WP_011141003 } \\
.1\end{array}$ & $5.0 \mathrm{E}-124$ \\
\hline
\end{tabular}

